\title{
Improving the Methodology of Disposition of State Support Funds for Agriculture under the WTO Rules
}

\author{
Anatoliy Timofeevich Stadnik ${ }^{1}$, Sergey Aleksandrovich Shelkovnikov ${ }^{1}$, Yvgeniy Vladimirovich Rudoy ${ }^{1}$, Danil \\ Maksimovich Matveev ${ }^{1} \&$ Marina Sergeevna Petukhova ${ }^{1}$ \\ ${ }^{1}$ Novosibirsk State Agrarian University, Novosibirsk, Russian Federation \\ Correspondence: Danil Maksimovich Matveev, Dobrolyubova Street, 160, Novosibirsk, 630039, Russian \\ Federation.
}

Received: December 10, 2014 Accepted: February 15, 2015 Online Published: May 22, 2015

doi:10.5539/ass.v11n14p133 URL: http://dx.doi.org/10.5539/ass.v11n14p133

\begin{abstract}
The author considers the current financial status and the efficiency of agriculture in Russia, evidenced from the Novosibirsk Region, as one of the leading food producers in Siberia. The basic disadvantages in the system of indicators to assess the effectiveness of state-run programs and the use of state support for the agricultural industry development are identified. The author has proposed the indicators enabling one to objectively reflect the current status of agricultural producers. These indicators can be used by the state when creating favorable conditions for expanded and innovative reproduction. They were used to determine deficiency of the state funding of the agricultural industry at different types of reproduction.
\end{abstract}

Keywords: agriculture, government regulation, technological progress, reproductive processes

\section{Introduction}

Ensuring food security of the country was of particular importance in the policy of any state at all times. Today, Russia needs it most urgently. Agriculture can be considered the second most important industry after oil and gas production.

One of the major problems of agriculture in Russia is a violation of various parameters of reproduction in the agricultural sector. These parameters help to improve the efficiency of agricultural production (e.g., significant technical and technological backwardness of agriculture, resulting from a violation of the reproduction process of primary factors of production).

Features of agriculture have a significant, predominantly negative impact on the reproduction process that necessitates identifying options and scenario forecasting of its development to support corrective package plan (Sidorov, 2012). The main condition for capital reconstruction is the availability of sufficient financial resources in enterprises. The sources of these resources can be both internal and external. Therefore, ensuring the effective management of this process requires monitoring and careful predictive studies of required investment resources in agriculture. This will give the opportunity to develop a policy in terms of reproduction, involving the use of amortization, profit, borrowed funds and other financial means (Menyaykin et al., 2014).

Provided adverse climatic conditions of Siberia and inability to cover the costs of gross production, as well as preserve farmland and ensure socio-cultural development of rural areas by the revenues from the agricultural organizations, regional agriculture needs state financial support.

Study of the works of leading scientists, dealing with the problem of state regulation of agriculture and making a significant contribution to the development of theory and practice, made it possible to determine the two main vectors of the research: first, improving the legal framework and increasing amounts of state support (Tyu, 2003; Emelyanov et al., 2009; Kolesnikov et al., 2014; Bistrov et al., 2014; Shishoff et al., 2013; Neshchadin, 2010; Bulanava, 2006; Sviridov and Petrenko, 2010; Koshelev and Danilova, 2008); second, financial recovery of the agricultural producers and improvement of credit and financial system providing the industry with financial resources (Urbanskaya, 2005; Yunyaeva, 2009; Proskurina, 2010; Voitleva, 2011; Charykova et al., 2012). Particular attention is paid to the state regulation of the availability of borrowed funds for agriculture and its investment attractiveness to private and foreign investors, both at the regional and federal level. 


\section{Methodology}

The methodology used in the current research included abstract and logical approach, monographic, economic and statistic techniques, as well as settlement and constructive method. Monitoring of targeted programs, methodologies and approaches to evaluate the effectiveness of state support for agriculture revealed their significant drawbacks. Thus, the existing system of indicators to assess the efficiency of agricultural production and its subsidization was supplemented applying abstract logical method.

Using the statistical research technique, the analytical grouping was conducted, which helped to identify the effect of state support on production efficiency of the agricultural organizations in the Novosibirsk Region and to develop the distribution map of agricultural enterprises of the Novosibirsk Region in terms of their level of profitability and economic return. The use of settlement and constructive method allowed author to define standards for budget support of agricultural enterprises in the Novosibirsk Region on the basis of the proposed methodological approach, taking into account the level of reproduction.

Conducted correlation and regression analysis revealed a relationship between the level of subsidization of agricultural production and accounts payable of agricultural enterprises.

\section{Results}

As part of the study, the analysis of today's financial status of agriculture in Russia was carried out. This revealed certain negative trends in its development, such as an increase in accounts payable that has a negative impact on financial stability and independence of agricultural producers. Another negative trend is associated with slowdown in the technical re-equipment of the agricultural industry, which was provided mainly due to the active involvement of borrowed funds.

The author proposed a scoring system that allows not only more objective evaluation of the agricultural organizations effectiveness, but also the use of the state financial support. The use of proposed indicators when monitoring the implementation of government programs will allow early identification of deviation from the intended course and making timely adjustment of the main activities aimed at developing the agricultural industry and improving the investment climate.

\section{Discussion}

During the years of Russian agricultural economic reforms in 90s, as well as in the whole economy, one could observe the decline in production, reduction in fixed assets, as well as a massive outflow of skilled labor and investment capital. Just in 2006 the government approved the priority national project "Development of Agriculture Sector" for the period from 2006 to 2007, which allowed formation of the main development vectors of rural areas in the country. Also, as part of this statute, a substantial increase in state support for agricultural producers was provided (Table 1). In the future, this project served a basis for the development of the State Program "Development of Agriculture and Regulation of Agricultural Commodities Markets, Raw Materials and Food for 2008-2012".

The highest growth of the state support was observed during the first years of program implementation. In subsequent years its increase was not more than $10 \%$ per year. In the funding dynamics the greatest changes were observed in the livestock farming, where the growth for the analyzed period amounted for 132.8 billion rubles (almost 4 times). Support of crop farming was provided on more stable basis (Table 1).

Table 1. Dynamics of the state investments into the fixed capital in agriculture, billion rubles

\begin{tabular}{|c|c|c|c|c|c|c|}
\hline Indicators / years & 2005 & 2006 & 2007 & 2008 & 2011 & 2012 \\
\hline $\begin{array}{l}\text { The total amount of state investments into the fixed capital in agriculture. } \\
\text { including: }\end{array}$ & 78.8 & 140.0 & 211.8 & 236.5 & 259.3 & 281.3 \\
\hline - crop farming & 33.7 & 53.2 & 78.2 & 93.7 & 84.4 & 87.8 \\
\hline - livestock farming & 44.5 & 84.3 & 130.1 & 136.5 & 165.9 & 177.3 \\
\hline
\end{tabular}

However, the level of financial flows into the agricultural production is still low. In 2006, investment intothe industry fixed capital amounted to about $3 \%$ of the total volume of the country's economy. This is mainly due to the fact that agriculture, as a sector of economy, is exposed to more risks than industry or services, and is not able to provide a stable competitive return on invested capital (Menyaykin et al., 2014).

The main lines of state support for agriculture in the period from 2006 to 2012 included the construction of buildings and industrial facilities, as well as updating the machine and tractor fleet. The amount of funding for these purposeshas increased by 8.4 and 2.4 times, respectively (Table 2). 
Table 2. Structure of state investments from the federal budget into the fixed capital in agriculture, billion rubles

\begin{tabular}{|c|c|c|c|c|c|c|}
\hline Indicators / years & 2005 & 2006 & 2007 & 2008 & 2011 & 2012 \\
\hline $\begin{array}{l}\text { The total amount of state investments into the fixed capital in agriculture. } \\
\text { including: }\end{array}$ & 78.8 & 236.5 & 198.0 & 203.7 & 259.3 & 281.3 \\
\hline - dwellings & 0.5 & 1.0 & 1.2 & 0.9 & 1.4 & 1.2 \\
\hline - buildings (except residential) and structures & 13.2 & 83.7 & 81.5 & 87.9 & 101.9 & 111.3 \\
\hline - machinery, equipment, and vehicles & 43.5 & 116.2 & 75.6 & 74.3 & 105.3 & 110.6 \\
\hline - other & 21.6 & 35.6 & 39.7 & 40.6 & 50.7 & 58.2 \\
\hline
\end{tabular}

Russia's accession to the World Trade Organization (WTO) required adjustment of the state support lines and amount of financing that were reflected in the State Program "Development of Agriculture and Regulation of Agricultural Commodities Markets, Raw Materials and Food for 2008-2012". The Programwas to provide the following:

1. The country's food sovereignty within the parameters specified by Food Security Doctrine of the Russian Federation.

2. Reproduction and enhancement of efficient use of agricultural land and other natural resources, as well as green production.

3. Sustainable development of rural areas.

4. Improving the competitiveness of Russian agricultural products in domestic and foreign markets based on innovative development of agribusiness, creating an enabling environment for entrepreneurial development, and increasing the investment attractiveness of the industry.

5. Ensure the financial sustainability of agribusiness industry producers (RF Government Resolution of July 14, 2012, №717).

In 2014, the largest share in the structure of expenditure under the State Program occurs on the development of the livestock farming, as well as processing and sale of industry products that amounts for 92.3 billion rubles (36.3\%). To support crop farming, processing and crop product sales, as well as elite seed farming, 43.4 and 13.9 billion rubles were allocated, respectively. State investments in technical and technological modernization and innovative development throughout the whole period of Program implementation will be an average of 3.58 billion rubles annually.

An effective mechanism for encouraging investments is subsidizing of credit interest rates of agricultural producers. In a number of the Russian Federation entities, the amount of funding under this cost item is up to $60-70 \%$ of the total funds allocated from the federal budget. Currently, the total debt on obligations of agricultural organizations in the Russian Federation is about 1.43 trillion rubles that is 3 times more than that in 2007. The amount of the debts on bank credits increased by 5 times and amounted for 1.0832 trillion rubles. Such level of debt load in the context of high-risk and low production efficiency has negative impact on the financial status of many commercial farm units.

Starting from 2013, the basic statutory instrument, determining the development of agriculture in Russia, is the State Program "Development of Agriculture and Regulation of Agricultural Commodities Markets, Raw Materials and Food for 2013-2020". Prognosis nits implementation is based on the achievement of number of indicators, as well as specific indices showing the implementation of the subprograms and federal target programs, included into the State Program.

As part of the State Program's main indicators, the following economic prognosis is expected:

1. The index of agricultural production in all categories of farms by 2020 compared to 2012 will amount for $120.8 \%$, including crop production (121.2\%) and livestock production (120.2\%);

2. The index of food production, including beverages by 2020 compared to 2012 will reach $135 \%$;

3. The index of physical quantity of investments into the fixed capital in agriculture in 2020 compared to 2012 will be $142 \%$;

4. The level of profitability throughout the whole economic activity of the agricultural organizations by 2020 will be at least $10-15 \%$ (including subsidies);

5. The proportion of wages in the agricultural organizations and the average wage in the national economy by 2020 will reach 55\% (Government Resolution of July 14, 2012, №717). 
We see that the key performance indicator of agricultural enterprises is the level of profitability assessed throughout all economic activities.

Table 3. Classification of agricultural enterprises of the Novosibirsk Region in terms of output profitability inclusive the subsidies for 2013

\begin{tabular}{|c|c|c|c|c|c|c|c|}
\hline \multirow{2}{*}{ № } & \multirow{2}{*}{$\begin{array}{l}\text { Organizations zoning depending } \\
\text { on their efficiency }\end{array}$} & \multirow[t]{2}{*}{ Criterion } & \multicolumn{2}{|c|}{$\begin{array}{c}\text { Number of } \\
\text { organizations }\end{array}$} & \multirow{2}{*}{$\begin{array}{l}\text { Relative variationin } 2013 \text { as } \\
\text { compared to } 2012, \%\end{array}$} & \multicolumn{2}{|c|}{$\begin{array}{c}\text { Persentage in tota } \\
\text { amount, \% }\end{array}$} \\
\hline & & & 2013 & 2012 & & 2013 & 2012 \\
\hline 1 & $\begin{array}{l}\text { Highly profitable } \\
\text { (green zone) }\end{array}$ & $\mathrm{R}_{\text {output }} \geq 40 \%$, & 45 & 40 & 112.5 & 10.4 & 9.7 \\
\hline 2 & $\begin{array}{l}\text { Commercially viable } \\
\text { (blue zone) }\end{array}$ & $\begin{array}{c}0 \% \leq \mathrm{R}_{\text {output }}< \\
40 \%\end{array}$ & 270 & 304 & 88.8 & 62.4 & 74.2 \\
\hline 3 & $\begin{array}{c}\text { Marginal } \\
\text { (purple zone) }\end{array}$ & $\mathrm{R}_{\text {output }} \leq 0 \%$ & 118 & 65 & 181.5 & 27.2 & 16.1 \\
\hline & Total & & 433 & 409 & - & 100 & 100 \\
\hline
\end{tabular}

Analysis findings of agricultural enterprises in the Novosibirsk Region showed a noticeable predominance of the second group of organizations, which includes the economies with the level of production profitability ranged from 0 to $40 \%$. This pattern characterizes a favorable situation in the regional agriculture, since more than $60 \%$ of organizations are commercially viable (Table 3). In 2012, the proportion of profitable farms was $70 \%$ out of the total number. During the year, the number of commercially viable organizations decreased by $10 \%$ (according to the accounting statements of agricultural producers of the Novosibirsk Region in 2013).

On average, in the Novosibirsk Region, the level of profitability, taking into account the state support, is $32.7 \%$. The highest profitability in 2013 was achieved in the Bagan (39.5\%) and the Kuibyshev (39.1\%) districts. In Kochkovsky and Maslyaninsky districts the aggregate agricultural production proved unprofitable, the loss ratio was $-2.5 \%$ and $-5.2 \%$, respectively.

In our opinion, the indicator on "profitability level" of agricultural organization, unlike other performance indicators, not reliably assesses the agricultural production effectiveness. This is a biased indicator of the effectiveness of agricultural organization, because it takes into account only the cost of products sold, rather than the gross output; it does not reflect the efficiency of the whole agricultural production, as only part of produced goods is a commodity, and the rest is used within the agricultural organization.

In addition, the level of profitability distorts the real pattern of the production efficiency, calculated at the end of the current year, because it can take into account the profit derived from the sale of products, produced in the past calendar year.

Based on the "profitability level" indicator, public authorities become hostages of well-being appearance in agricultural industry and do not take into account the actual situation when determining the amount of funding the agricultural production and the disposition of state funds (Shelkovnikov, 2010).

Therefore, for a comprehensive analysis and planning of the agricultural production efficiency it is necessary to supplement the existing system of performance indicators by the coefficients suggested by Professor Shelkovnikov. This would allow us to objectively evaluate the multiple factors and conditions in agriculture, make reliable conclusions about the main development lines of agricultural production. These coefficients include:

The rate of recoupment of expenses on core production $\left(\mathrm{RRE}_{\text {actual }}\right)$ reflects how the revenue from the sale of products (B) covers the costs incurred by the agricultural enterprises on the core production $(\mathrm{C})$, and is calculated as follows:

$$
\mathrm{RRE}_{\text {actual }}=\mathrm{B} / \mathrm{C}
$$

1. The accounts receivable (AR), available in the agricultural enterprises, as part of the revenue, according to the accounting rules, is, in fact, its lost part, and can be accounted by the coefficient of actual recoupment of expenses $\left(\mathrm{CRE}_{\text {actual }}\right)$, based on production of agricultural organization:

$$
\mathrm{CRE}_{\text {actual }}=(\mathrm{B}-\mathrm{AR}) / \mathrm{C}
$$

2. Adjusting $\mathrm{CRE}_{\text {actual }}$ in terms of the subsidies on core production $\left(\mathrm{Sub}_{\text {core }}\right)$ we get the actual rate of recoupment of expenses, taking into account the cost of subsidies for core production $\left(\mathrm{CRE}_{\text {actual,sub. }}\right)$ : 


$$
\mathrm{CRE}_{\text {actual, sub. }}=\left((\mathrm{B}-\mathrm{AR})+\mathrm{Sub}_{\text {core }}\right) / \mathrm{C}
$$

From mentioned above it can be concluded that for more objective assessment of the efficiency of agricultural producers, the analysis of their activity, based on the assessment of their profitability level, should be supplemented by the proposed coefficients of expenses recoupment, which are calculated using the gross output production costs and overall costs of the organization. This allows one to fully take into account the specificity of agricultural production. These coefficients reflect the actual situation in the agriculture and can be used as indicators to develop conditions that should be provided by the state to enable expanded innovative reproduction of the agricultural organization (Shelkovnikov, 2010).

Let compare the results, obtained by the assessment of the agricultural production efficiency based on the profitability and the rate of recoupment of expenses, and let analyze agricultural enterprises of the Novosibirsk Region using the actual rate of recoupment with due consideration of the state financial support.

Table 4. Classification of agricultural enterprises of the Novosibirsk Region based on actual rate of recoupment, inclusive of the budget subsidies for 2013

\begin{tabular}{|c|c|c|c|c|c|c|c|}
\hline \multirow[t]{2}{*}{ № } & \multirow{2}{*}{$\begin{array}{l}\text { Organizations zoning depending on their } \\
\text { efficiency }\end{array}$} & \multirow[t]{2}{*}{ Criterion } & \multicolumn{2}{|c|}{$\begin{array}{c}\text { Number of } \\
\text { organizations }\end{array}$} & \multirow{2}{*}{$\begin{array}{c}\text { Relative variation in } \\
2013 \text { as compared } \\
\text { to } 2012, \%\end{array}$} & \multicolumn{2}{|c|}{$\begin{array}{l}\text { Persentage in } \\
\text { total amount, } \%\end{array}$} \\
\hline & & & 2013 & 2012 & & 2013 & 2012 \\
\hline 1 & Organizations with expanded reproduction & $\mathrm{CRE}_{\text {actual,sub. }} \geq 1.3$ & 11 & 11 & 100 & 2.6 & 2.7 \\
\hline 2 & Organizations with a simple production & $1 \leq \mathrm{CRE}_{\text {actual }, \text { sub. }}<1.3$ & 30 & 46 & 65.2 & 6.9 & 11.3 \\
\hline \multirow[t]{2}{*}{3} & Sunk organizations & $0 \leq \mathrm{CRE}_{\text {actual,sub. }}<1$ & 392 & 352 & 111.4 & 90.5 & 86 \\
\hline & Total & & 433 & 409 & - & 100 & 100 \\
\hline
\end{tabular}

The analysis shows that $90 \%$ of all agricultural organizations in the Novosibirsk Region are operating beyond the recoupment of expenses that causes the critical situation in the field of regional agriculture. Farms are not able to cover the costs of core production even with the budget subsidies to provide simple reproduction (Table 4). In 2012, the share of such organizations was equal to $82.2 \%$. During the year the number of such organizations was increased by $7.8 \%$. Many farms have gone bankrupt. This is due to the large accumulation of accounts payable of agricultural organizations and their inability to pay debts.

As follows from the analysis based on the actual rate of expenses recoupment, with due account for the budget subsidies, it was revealed that in the Novosibirsk Region $6.9 \%$ of organizations are those with a simple reproduction (vs. $62.4 \%$, if calculated based on the level of production profitability).

Author also calculated the regulatory standards for state support of farms of the Novosibirsk Region to provide a simple, expanded and innovative reproduction (reproduction option, when organizations are able not only to expand production, but also to implement new technologies and innovations, thereby increasing productivity).

Table 5. The regulatory standards for state support of agricultural organizations of the Novosibirsk Region (million rubles)

\begin{tabular}{lccc}
\hline \multirow{2}{*}{ Indicators } & \multicolumn{3}{c}{ Reproduction patterns } \\
\cline { 2 - 4 } & $\begin{array}{c}\text { Simple reproduction } \\
\left(\mathrm{CRE}_{\text {actual,sub. }}=1\right)\end{array}$ & $\begin{array}{c}\text { Expanded reproduction } \\
\left(\mathrm{CRE}_{\text {actual,sub. }}=1.3\right)\end{array}$ & $\begin{array}{c}\text { Innovative reproduction } \\
\left(\mathrm{CRE}_{\text {actual,sub. }}=1.5\right)\end{array}$ \\
\hline $\begin{array}{l}\text { The regulatory standard for subsidies, } \\
\text { million rubles }\end{array}$ & 6585.6 & 17561.2 & 24878.3 \\
Additional demand for subsidies, million rubles & 3240.4 & 14216.0 & 21533.1 \\
\hline
\end{tabular}

To ensure simple reproduction, the agricultural organizations of the Novosibirsk Region required in 2013 additional 3.24 billion rubles, i.e. 2 times more than the state budget allocations. At that, the expanded reproduction would require fivefold increase in state funding, whereas innovative reproduction would demand sevenfold increase.

Thus, $90.5 \%$ of the agricultural organizations in the Novosibirsk Region are unable to provide even simple reproduction. The problem consists in the lack of financial resources to ensure the regular reproductive processes. 
The drought of 2012 and the rains of 2013, Russia's accession to the World Trade Organization, the rise in energy prices and instability in purchase prices for agricultural products have led to a high level of accounts payable in agriculture. After a crop failure in 2012, many organizations borrowed funds against the harvest of 2013, which also turned out to be quite poor. This was the main impetus for the increase in accounts payable of farms. Currently about $30 \%$ of the farms in the Novosibirsk Region cannot service their loans and are on the verge of bankruptcy. Whereas in 2012 and 2013, banks made advances and were ready for refinancing of agricultural organizations that saved the situation, in 2014 they blocked such a possibility in connection with a high level of accounts payable of agricultural organizations. Presently, only large agricultural producers, who are still able to discharge their obligations, can afford themselves to take credits. In this situation, it makes no sense to talk about any development of the industry; everything evidences on the disappearance of small and medium-sized farms (and, consequently, entire villages and rural communities), and the market monopolization.

According to the Ministry of Agriculture of the Novosibirsk Region, as of April 1, 2014, the amount of credits granted to Novosibirsk farmers was 113.1 million rubles (172.2 million rubles as of April 1,2013). Also, at the end of 2013, 32 agricultural organizations in the region underwent the various bankruptcy procedures. Among them 8 organizations completed bankruptcy proceedings, while 3 organizations terminated such proceedings: two terminations resulted from the conclusion of amicable agreement, and one termination was due to the refusal of the claim by the bankruptcy creditor.

Financial recovery program is being carried out in 119 organizations of the agro-industrial complex of the Novosibirsk Region. The Russian Federation government pursues an aggressive policy in improving credit availability and ease of payment. In 2014, 44 billion rubles are allocated to subsidies from the federal budget to reimburse part of the interest rate on investment loans. However, this type of support "lies" in the yellow basket of the WTO, which has limitations on funding and is subject to reduction. In addition, the Ministry of Agriculture along with the Ministry of Finance propose to reallocate funds within the State Program on agriculture development, to be received by the enterprises most in need. In the current year, to finance the State Program, 170 billion rubles were allocated from the federal budget.

In agriculture, in addition to a variety of external factors (drought, rain, Russia's accession to the WTO) the amount of accounts payable of agriculture organizations also is affected by the amount of subsidies from the federal and regional budgets. Let consider the trend and the correlation ratio of this relationship using correlation and regression analysis, and derive the regression equation.

Let take the difference between total amount of the state support for agricultural organizations in the reporting period and that of prior period $\Delta \mathrm{Sub}$ as an indication factor. Let take a similar change in accounts payable $\Delta \mathrm{AP}$ as resultant variable. To build the model we take the data from the financial statements of agricultural enterprises of the Novosibirsk Region for 2012-2013.

The regression equation is as follows:

- $y=-12.8 \mathrm{x}+19344$.

- The correlation coefficient is -0.72 .

- The equation is significant with a probability of $95 \%$, a change in the resultant variable by $52 \%$ is due to the change in the indication factor.

Thus, there is a strong inversely proportional correlation between $\triangle \mathrm{Sub}$ and $\triangle \mathrm{AP}$.

That is, an increase in $\Delta \mathrm{Sub}$ leads to reduction in $\triangle \mathrm{AP}$ (i.e. increase in the amount of state support in the reporting year leads to a decrease in accounts payable of agricultural enterprises in the reporting year as compared to that in the previous year).

Now let carry out correlation and regression analysis between the amount of subsidies from the federal and regional budgets ( $\mathrm{Sub}$ ), and the accounts payable in a reporting financial year (AP).

The regression equation is as follows:

- $\quad \mathrm{y}=0.04 \mathrm{x}+4903.8$

- $\quad$ The correlation coefficient is 0.4 ;

- The equation is significant with a probability of $95 \%$.

In this case, there is a moderate direct correlation between the studied parameters, i.e. the greater the amounts of state support for agricultural organizations, the greater the accounts payable. 
Thus, based on the results of the two models, we can conclude that when comparing $\Delta \operatorname{Sub}$ and $\Delta$ APindicators in terms of time, increasing the amount of state support in the reporting period leads to a decrease in accounts payable of agricultural producers in the same period compared to the previous period. However, the larger the amount of subsidies received by the organization from the federal and regional budgets, the greater the amount of its liabilities. The amount of these subsidies depends on various target indicators of the organization, i.e. the larger and the efficient the agricultural production, the more subsidies it receives. In such farms, the subsidies received from the budget, usually are spent for the purchase of agricultural machinery, agricultural modernization etc. that certainly leads to accrued accounts payable, though with increasing amounts of subsidies in the following year the debt will be reduced (Stadnyk et al., 2014) .

\section{Conclusion}

From the abovementioned, it can be concluded that in transition economies the most effective method of agricultural management is a market-indicative method. It is based on the definition of the various performance indicators of agricultural production efficiency. For a more objective assessment, the existing system to determine the effectiveness of the agricultural organizations must be supplemented by the expenses recoupment coefficients, which are calculated using the costs of the gross output production and overall costs of agricultural producers, enabling fuller accounting for the specificity of agricultural production. These coefficients reflect the real situation in agriculture and can be used by the state as indicators to provide the conditions, enabling expanded innovative reproduction.

Market-indicative control method can be used both at the federal and regional levels. However, at the federal level, this method is not efficient enough, because performance indicators of agricultural production are based on average indicators for the whole Russia. This is not enough to reflect the actual situation in the industry due to the essential differences in climatic-environmental conditions in the country regions. However, at the regional and municipal levels, as well as within the particular agricultural organization, this technique is quite effective.

The rates of expenses recoupment should be the major indicators during the disposition of state support funds and assessment of its effectiveness.

State support has a significant effect on agricultural activity. As shown by correlation and regression analysis, increasing the amount of subsidies leads to a decrease in accounts payable, and solves thereby the pressing problem of a high level of accounts payable of agriculture.

\section{References}

Bulanova, Yu., \& Polyakova, T. (2006). On state regulation of agriculture. Bulletin of the Novosibirsk State Agrarian University, 5, 84-86.

Bystrov, G., \& Pobezhimova, N. (2014). State regulation of agriculture. Eurasian Law Journal, 2(69), 148-156.

Charykova, O., \& Novichikhina, N. (2012). State regulation of agriculture in contemporary conditions. FES: Finance, Economy, Strategy, 12, 5-9.

Emelyanov, S., Zolotoreva I., Minakova, I., \& Shatokhin M. (2009). State regulation of agriculture in the region. Kursk.

Kolesnikov, A. (2011). State support and regulation of agriculture in Germany. Agribusiness: Economics andManagement, 9, 87-90.

Kolesnikov, A., Stebleva, N., \& Shishkina, N. (2014). Financial support and state regulation of agriculture in the leading countries of the European Union and the United States. Bulletin of the Voronezh State Agrarian University, 1(2), 294-302.

Koshelev, B., \& Danilova, T. (2008). State regulation of agriculture at the regional level. Omsk.

Matveev, D. (2014). Peculiarities of elaborating the strategy for the meat market development in the regions of the Russian Federation. Life Science Journal, 11(11), 350-355.

Matveev, D., Stadnik, A., \& Menyaykin, D. (2014). Foreign experience of state support for agriculture. Bulletin of the KrasGAU, 10, 45-51.

Neshchadin, A. (2010). State regulation of agriculture in Western countries. Machinery and Equipment for the Village, 2, 44-47.

On the State Program on Agricultural Development and Regulation of Agricultural Products, Raw Materials and Food for 2013-2020: Government Decree of July 14, 2012, №717. Retrieved May 4, 2014, from http://mcx.nso.ru/Documentation/ Documents/ВЦП\%20в\%20ред.\%20приказа\%20№53-нпа\%20от\%2027. 
05.2014.doc

Proskurina, N. (2010). State regulation of agricultural lending in Russia. Bulletin of the Orenburg State University, 13(119), 194-199.

Shelkovnikov, S. (2010). Formation and development of the state support mechanism of the agricultural production in the region. Moscow: NGAU.

Shishov, D., Shishov, A., \& Grishakin, N. (2013). State regulation of agriculture in the context of Russia's accession to the WTO. Proceedings of the St. Petersburg State Agrarian University, 30, 101-105.

Sidorova, D. (2012). Features of the reproduction process in agriculture (Ph.D. thesis). Stavropol.

Sviridov, V., \& Petrenko, N. (2010). State regulation of agriculture development based on indicative planning (regional aspect). Moscow.

The financial statements of the financial and economic status of agricultural producers in the Novosibirsk Region in 2013. The Ministry of Agriculture of the Novosibirsk Region.

Tyu, L. (2003). Improvement of the state regulation in the investment activity in agriculture (in Siberia). Development of regional agribusiness (pp. 137-139). Novosibirsk.

Urbanskaya, G. (2005). Improvement of state regulation in the investment activity in agriculture (in Siberia). Agricultural Economics. Refereed Journal, 2, 269-274.

Voitleva, Z. (2011). State regulation of agriculture as a tool to enhance its efficiency. New Technologies, 1, 43-46.

Yunyaeva, R. (2009). State regulation of the credit system in agriculture. Agribusiness: Economics and Management, 11, 32-37.

\section{Copyrights}

Copyright for this article is retained by the author(s), with first publication rights granted to the journal.

This is an open-access article distributed under the terms and conditions of the Creative Commons Attribution license (http://creativecommons.org/licenses/by/3.0/). 